\title{
1 Determinants of COVID-19 outcomes: A systematic review
}

2 Shirley Crankson*, Subhash Pokhrel, Nana Kwame Anokye

3 Division of Global Public Health, Department of Health Sciences, College of Health,

4 Medicine and Life Sciences, Brunel University London.

\section{Abstract}

7 Background: The current pandemic, COVID-19, caused by a novel coronavirus SARS-CoV-

8 2, has claimed over a million lives worldwide in a year, warranting the need for more

9 research into the wider determinants of COVID-19 outcomes to support evidence-based

10 policies.

11 Objective: This study aimed to investigate what factors determined the mortality and length 12 of hospitalisation in individuals with COVID-19.

13 Data Source: This is a systematic review with data from four electronic databases: Scopus,

14 Google Scholar, CINAHL and Web of Science.

15 Eligibility Criteria: Studies were included in this review if they explored determinants of 16 COVID-19 mortality or length of hospitalisation, were written in the English Language, and 17 had available full-text.

Study appraisal and data synthesis: The authors assessed the quality of the included studies with the Newcastle $\square$ Ottawa Scale and the Agency for Healthcare Research and Quality checklist, depending on their study design. Risk of bias in the included studies was assessed with risk of bias assessment tool for non-randomised studies. A narrative synthesis of the evidence was carried out. The review methods were informed by the Joana Briggs Institute guideline for systematic reviews.

Results: The review included 22 studies from nine countries, with participants totalling 239,830 . The included studies' quality was moderate to high. The identified determinants were categorised into demographic, biological, socioeconomic and lifestyle risk factors, based on the Dahlgren and Whitehead determinant of health model. Increasing age (ORs 1.04-20.6, 95\%CIs 1.01-22.68) was the common demographic determinant of COVID-19 mortality while living with diabetes (ORs 0.50-3.2, 95\%CIs -0.2-0.74) was one of the most common biological determinants of COVID-19 length of hospitalisation.

Review limitation: Meta-analysis was not conducted because of included studies' heterogeneity.

Conclusion: COVID-19 outcomes are predicted by multiple determinants, with increasing age and living with diabetes being the most common risk factors. Population-level policies that prioritise interventions for the elderly population and the people living with diabetes may help mitigate the outbreak's impact.

37 


\section{Strength and limitations of this review}

\section{Introduction}

57 COVID-19 (SARS-CoV-2, coronavirus) is currently among the leading causes of death

58 globally. As of January 9th, 2021, 87,589,206 cases and 1,906, 606 deaths had been recorded

59 globally (1). While its case fatality ratio (CFR) has been relatively low (CFR=2.2\%), 60 compared to CFRs of previous coronavirus outbreaks, notably, MERS (CFR=9.5\%) and 61 SARS-COV-1 (CFR=34.4\%), its aggressive and alarming transmission rate has posed 62 enormous challenges on global health (2). Even the current reported transmission rate of 
medRxiv preprint doi: https://doi.org/10.1101/2021.03.21.21254068; this version posted March 23, 2021. The copyright holder for this preprint (which was not certified by peer review) is the author/funder, who has granted medRxiv a license to display the preprint in perpetuity.

It is made available under a CC-BY-NC-ND 4.0 International license .

63 COVID-19 may be lower than the actual transmission rate because a significant proportion of

64 infected persons may remain undetected because they are asymptomatic (3). And regarding

65 its CFR, current predictions even suggest that mortality ratio may increase since the

66 pandemic is still ongoing (4). The infectivity and fatality rates associated with COVID-19,

67 together with the worldwide panic it generates, make the current coronavirus pandemic a

68 significant threat to public health, and its gargantuan impact unlike anything the world has

69 experienced in the last two decades (5).

71 Since its inception, COVID-19 has overburdened the whole global health system, from 72 crippling health resources to causing paradigm shifts in health care delivery (6). The testing 73 process, quarantine and isolation associated with the virus has had dire psychological and

74 financial implications on individuals and institutions (7). Furthermore, lockdowns instituted

75 by affected countries to curb the virus's spread resulted in disrupted formal education,

76 unplanned fiscal costs on emergency reliefs, and decreased productivity, all translating into

77 huge economic costs to governments and organisations (8). The overall COVID-19 burden, in

78 terms of health and fiscal implications, has been consequential in both high-income and low-

79 and middle-income countries, albeit with contextual differences.

80 Regardless of the significant interventions to curb the virus's spread and subsequently reduce

81 its severest outcome, i.e., mortality and morbidity, the outbreak continue to increase. As of

82 January 9th, 2021, the daily global COVID death was 15,522, the highest daily mortality

83 since the pandemic started, and about 3,000 more deaths since the first peak in daily COVID-

8419 deaths (initial peak April 17th - 12,511 daily deaths) (1). Also, 823,856 cases were

85 confirmed on January 9th, 2021, representing a $0.93 \%$ increase from the previous day's case

86 count. The rapid rise in the COVID-19 cases and deaths worldwide necessitates continuous 
medRxiv preprint doi: https://doi.org/10.1101/2021.03.21.21254068; this version posted March 23, 2021. The copyright holder for this preprint (which was not certified by peer review) is the author/funder, who has granted medRxiv a license to display the preprint in perpetuity.

It is made available under a CC-BY-NC-ND 4.0 International license .

87 research on risk factors for COVID-19 outcomes to provide current evidence-based 88 interventions to reduce the outbreak's drastic impact.

90 Several studies on determinants of COVID-19 outcomes were identified in the literature;

91 however, most of them were primary studies investigating risk factors for COVID-19

92 mortality $(9,10,11)$. The few secondary studies/systematic reviews found in the literature

93 encompassed only papers from high-income countries (12, 13). Also, there is inadequate

94 coverage on other COVID-19 outcomes, specifically, length of hospital stay (LOS). Till date,

95 no review has explored risk factors/determinants of COVID-19 LOS. Findings from such

96 studies will be essential for help health systems to develop contingency plans for bed

97 occupancy and health resources, especially with the swift increase in the COVID-19 cases.

98 Thus, this study aimed to review factors that determine COVID-19 mortality and LOS in

99 individuals diagnosed with COVID-19 to address the literature dearth and contribute to

100 global efforts at curtailing the pandemic. Understanding the risk factors of COVID-19

101 outcomes based on a comprehensive synthesis of global but rapidly emerging evidence might

102 be useful to implement effective policies to address the disease burden.

103 Methods

104 Search strategy

105 From $21^{\text {st }}$ to $31^{\text {st }}$ December 2020, Scopus, Google Scholar, CINAHL and Web of Science

106 databases were searched for relevant studies using the search terms: 'Determinants'

107 'Predictors' 'COVID-19' 'SARS-CoV-2' 'Mortality' 'Length of hospital stay' 'Length of

108 hospitalisation'. The search terms were combined with mesh words and Boolean operators to

109 ensure sensitive and targeted search. Full search strategy is shown in supplementary 
medRxiv preprint doi: https://doi.org/10.1101/2021.03.21.21254068; this version posted March 23, 2021. The copyright holder for this preprint (which was not certified by peer review) is the author/funder, who has granted medRxiv a license to display the preprint in perpetuity.

It is made available under a CC-BY-NC-ND 4.0 International license .

110 information 1. First screening of the databases results was conducted independently by two of

111 the reviewers (SC and NKA) to ensure their relevance to this study. The tiles and abstract of

112 the identified relevant studies were screened against this review's eligibility using the

113 following predetermined eligibility criteria: population - individuals diagnosed with COVID-

114 19, exposures - demographic, socioeconomic, lifestyle, environmental biological/medical

115 factors, outcome - COVID-19 related mortality and LOS, studies that explored determinants

116 of COVID-19 mortality and LOS in participants with COVID-19, studies whose LOS

117 endpoint was discharge or death, and not hospital transfers, studies written and published in

118 the English Language, and with full-text available. No date restriction was applied in any of

119 the databases since most COVID-19 studies are recent. No database filters were also applied.

120 The references of the identified papers were also tracked for papers eligible for this

121 review. Any disagreements relating to studies' screening was discussed and resolved with the

122 third reviewer (SK) and

\section{Data extraction}

125 Two of the authors (SC and NKA) extracted the relevant data from the included studies using

126 a comprehensive a priori developed set of data extraction questions (Supplementary

127 information 2), informed by the JBI data extraction tools. The questions were categorised

128 under two main themes, i.e., general information (authors name, study settings, study aim,

129 year of publication) and methodology (sample size, sample characteristics, outcomes etc.), to

130 ensure the sensitivity of the questions to the overarching objectives of this review. The data

131 extraction questions were piloted-tested on five selected studies before their final usage. The

132 third author (SP) randomly selected and reviewed $50 \%$ of the extracted data from the 
medRxiv preprint doi: https://doi.org/10.1101/2021.03.21.21254068; this version posted March 23, 2021. The copyright holder for this preprint (which was not certified by peer review) is the author/funder, who has granted medRxiv a license to display the preprint in perpetuity.

It is made available under a CC-BY-NC-ND 4.0 International license .

133 included studies to ascertain data extraction quality. Finally, all disagreements were resolved 134 by consensus.

136 Risk of bias and quality assessment

137 The Newcastle $\square$ Ottawa Scale (NOS) and the Agency for Healthcare Research and Quality 138 (AHRQ) appraisal checklist were used to appraise the quality of the included studies. These 139 checklists were based on a systematic review's recommendation (14). The NOS provides 140 eight items grouped under three main domains: the selection of cohorts, the comparability of 141 cohorts, and outcomes assessment. A star (*) was awarded if a study met an item under the 142 three defined domains. A maximum of one star was given to items within the selection and 143 outcome domain, and a maximum of two stars was given to the item under the comparability 144 domain. Thus, studies with nine stars were rated as high-quality study and those with two 145 stars or less were graded as low quality. Like the NOS, the ARHQ also provides 146 items/checklists $(\mathrm{n}=11)$ for assessing the quality of the study's' methods and outcomes. A 147 'yes', 'no' or 'not applicable (NA)' was used to indicate whether a study met the AHRQ 148 requirement. The number of 'yes' from a study represented the study's quality. Consequently, 149 studies with eleven 'yes', suggesting 11 total scores, were ranked as high quality, whereas 150 those with two or less 'yes' were rated as low quality. Also, risk of bias assessment of both 151 the study and outcome level of the included papers was performed with risk of bias 152 assessment tool for non-randomised studies. The quality and risk assessment findings are 153 presented in supplementary information 3. 
medRxiv preprint doi: https://doi.org/10.1101/2021.03.21.21254068; this version posted March 23, 2021. The copyright holder for this preprint (which was not certified by peer review) is the author/funder, who has granted medRxiv a license to display the preprint in perpetuity.

It is made available under a CC-BY-NC-ND 4.0 International license .

\section{Data synthesis}

156 Descriptive data synthesis, informed by the JBI manual for evidence synthesis in systematic

157 reviews was conducted to comprehensively describe the methods, findings, and quality of the

158 included studies (15). The studies' methods, its operationalisation and the subsequent

159 findings were compared across the papers to identify common determinants of COVID-19

160 mortality and LOS. Also, the range of effect sizes (odds ratios/hazard ratios) of the identified

161 determinants in the studies were synthesised to understand the magnitude of the effect on the

162 study outcomes. This was done by reporting the lowest and highest effect sizes from studies

163 that identified common determinants.

165 Patient and public involvement

166 This study reviewed already published and available research. Therefore, no patients or the

167 public were directly involved in this review process. The findings of this review will be 168 shared publicly through scientific publication, social media, and conference presentations.

\section{Results}

\section{Search result}

172 The database search yielded 1,653 studies. The authors removed 11 duplicates and eliminated 173 a further 1,564 after title screening for relevance to this review. The abstracts of the 174 remaining 78 studies were assessed for eligibility using the predetermined eligibility criteria.

175 Twenty-two studies met the inclusion criteria and were subsequently included in this review, 176 as shown in the Prisma flow diagram below (Fig 1). 
medRxiv preprint doi: https://doi.org/10.1101/2021.03.21.21254068; this version posted March 23, 2021. The copyright holder for this preprint (which was not certified by peer review) is the author/funder, who has granted medRxiv a license to display the preprint in perpetuity.

It is made available under a CC-BY-NC-ND 4.0 International license .

178

179

180

181

182

183

184

185

186

187

188

189

190

191

192

193

194

195

196

197

198

199

200

201

202

203

204 Fig 1. Prisma flow diagram showing the literature search.
Records identified from all databases

(Total $\mathrm{n}=1,653$ )

Google Scholar $(n=1,510)$

Scopus $(\mathrm{n}=32)$

CINAHL $(n=16)$

Web of Science $(n=95)$

Records after duplicates removed

$$
(\mathrm{n}=1,642)
$$
eligibility

$(n=78)$

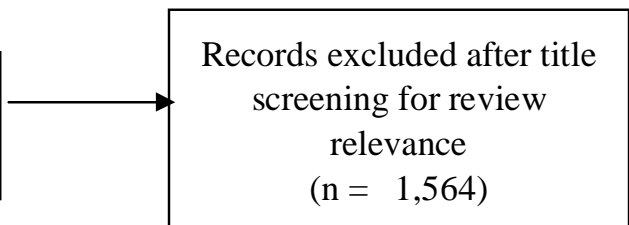

Studies included in qualitative synthesis

$$
(n=22)
$$


medRxiv preprint doi: https://doi.org/10.1101/2021.03.21.21254068; this version posted March 23, 2021. The copyright holder for this preprint (which was not certified by peer review) is the author/funder, who has granted medRxiv a license to display the preprint in perpetuity.

It is made available under a CC-BY-NC-ND 4.0 International license .

\section{Overview of included studies}

207 The studies spanned nine major countries, of which eight were high-income countries and 208 one upper-middle-income country. Majority of them were from China $(n=6)$ and USA (n=6), 209 followed by Spain ( $\mathrm{n}=2)$, and England ( $\mathrm{n}=2)$, and one each from Kuwait, Mexico, France, 210 Italy, Austria, and one multi-continent study- participants from Africa, Europe, Australia, 211 Asia, and Americas (16). They all used the quantitative research approach, with retrospective 212 cohort design as the predominant study design $(n=12)$. Most of them $(n=20)$ accessed only 213 secondary data, retrieved mainly from the patients' electronic medical records. The remaining 214 two used both secondary and primary data (face to face and telephone interviews) $(10,17)$.

215 The studies sample size ranged from 58 to 177,133 , totaling 239,830 participants. All the 216 studies included both male and female participants; however, the men dominated, 217 representing $51.4 \%$ of the studies' entire population. Only 7 studies were age-specific 218 limited their inclusion to participants $\geq 18$ years old. The majority $(n=20)$ included only 219 persons with confirmed COVID-19 test, either through the reverse transcription-polymerase 220 chain reaction (RT-PCR) or nasopharyngeal swabs. The other two studies included all 221 confirmed, negative, and suspected, and both suspected and confirmed COVID-19 cases (18,

222 19) (Table 1). The studies' quality on the NOS and AHRQ ranged from 6-9, representing 223 moderate to high quality and the common risk of bias across the studies was the inability to 224 control the influence of unmeasured confounders. This confounding bias inherently 225 influenced the studies' findings and could subsequently affect this review's finding.

227 Of the COVID-19 outcomes, 19 studies focused on only COVID-19 mortality, 2 solely on 228 COVID-19 LOS and 1 on both COVID-19 mortality and LOS. Mortality was generally 229 described as either in-hospital deaths, i.e., deaths occurring in a hospital or all-cause 
medRxiv preprint doi: https://doi.org/10.1101/2021.03.21.21254068; this version posted March 23, 2021. The copyright holder for this preprint

(which was not certified by peer review) is the author/funder, who has granted medRxiv a license to display the preprint in perpetuity.

It is made available under a CC-BY-NC-ND 4.0 International license .

230 mortality, i.e., all deaths in COVID-19 patients, regardless of the cause. LOS was also

231 defined commonly as the number of days in hospital admission due to COVID-19. One study

232 described it as normal or prolonged, based on their measured average LOS ( $<17$ days -

233 normal; >17 - prolonged) (20). Consequently, they assessed LOS as a binary outcome. On the

234 determinants of COVID-19 outcomes, identified risk factors were categorised into

235 demographic, lifestyle, socioeconomic and biological/medical determinants, based on the

236 determinants of health model (21). The rationale was to provide contextual analysis and

237 identify common risk factors for COVID-19 outcomes. The biological/medical determinants

238 encompassed as comorbidities, laboratory findings, and participants symptoms. The findings

239 of the studies are synthesised below (Table 2). 
Table 1: Study characteristics

$\begin{array}{lllll}\text { Studies } & \text { Aim } & \text { Settings } & \begin{array}{l}\text { Sample } \\ \text { size }\end{array} & \begin{array}{l}\text { Sample characteristics } \\ \text { (definition) }\end{array}\end{array}$

\begin{tabular}{|c|c|c|c|c|c|}
\hline $\begin{array}{l}\text { Alaa et al. } \\
(2020)(22)\end{array}$ & $\begin{array}{l}\text { To investigate the influence of } \\
\text { timing of hospital admission on } \\
\text { risk of mortality for patients } \\
\text { with COVID-19 in England }\end{array}$ & & & $\begin{array}{l}\text { Individuals with COVID-19 in the CHESS } \\
\text { database during the study period. Average age - } \\
68 \text { years, Men }-61 \%\end{array}$ & $\begin{array}{l}\text { Mortality (all } \\
\text { cause-mortality) }\end{array}$ \\
\hline $\begin{array}{l}\text { Almazeedi } \\
\text { et al. (2020) } \\
(23)\end{array}$ & $\begin{array}{l}\text { To examine the demographics, } \\
\text { clinical manifestations, and } \\
\text { outcomes in patients with } \\
\text { COVID-19 }\end{array}$ & $\mathrm{Ku}$ & 1096 & $\begin{array}{l}\text { All COVID-19 patients admitted to Jaber Al } \\
\text { Ahmad Al-Sabah hospital in Kuwait, with } \\
\text { COVID- } 19 \text { diagnosis based on WHO guideline } \\
\text { and confirmed Polymerase Chain Reaction } \\
\text { (PCR) test. Average age - } 41 \text { years, Men }-81 \% \text {. }\end{array}$ & $\begin{array}{l}\text { Mortality (in- } \\
\text { hospital mortality) }\end{array}$ \\
\hline $\begin{array}{l}\text { Bello- } \\
\text { Chavolla et } \\
\text { al. (2020) } \\
\text { (18) }\end{array}$ & $\begin{array}{l}\text { To examine the association } \\
\text { between diabetes and SARS- } \\
\text { CoV-2 infection and its } \\
\text { consequent clinical outcomes }\end{array}$ & & 177 & $\begin{array}{l}\text { All confirmed, negative, and suspected COVID- } \\
19 \text { cases in the Mexican } \mathrm{MOH} \text { dataset. Average } \\
\text { age }-46.7 \text { years, Men }-57.7 \%\end{array}$ & Mortality \\
\hline $\begin{array}{l}\text { Berenguer } \\
\text { et al. (2020) } \\
\text { (11) }\end{array}$ & $\begin{array}{l}\text { To examine the predictors of } \\
\text { death in patients with COVID- } \\
19 \text { in Spain }\end{array}$ & Spain & 4035 & $\begin{array}{l}\text { Males }(61 \%) \text { and females (39\%) with COVID- } \\
19 \text { confirmed by real-time PCR assay in } 127 \\
\text { Spanish centres. Average age }-70 \text { years, Men - } \\
61 \%\end{array}$ & $\begin{array}{l}\text { Mortality (all-cause } \\
\text { mortality) }\end{array}$ \\
\hline
\end{tabular}


Carrasco- To examine the association Spain Sánchez et between blood glucose levels al. (2020) and in-hospital mortality in noncritically patients with COVID19.

Halalau et To provide risk assessment tools USA al. (2020) for patients with COVID-19.

Kaeuffer et To explore risk factors of severe France al. (2020) COVID-19 disease and mortality

$\mathrm{Li}$ et al. To investigate severity of China (2020) (10) COVID-19 outcomes

Okoh et al. To examine the clinical features USA

(2020) (27) of COVID-19 outcomes in Black/African American and Latino Hispanic

Petrilli et al. To explore in-hospital COVID- USA
11,312 Patients $\geq 18$ years with COVID-19 confirmed by Mortality (all-cause Reverse Transcription (RT)-PCR and mortality during hospitalized from 1 March 2020 to 31 May 2020. hospitalization) Average age -67.06 years, Men $-57.1 \%$

Patients with positive COVID-19 on Mortality (innasopharyngeal swabs at any Beaumont Health's hospital mortality) eight emergency departments between 1 March 2020 and 1 April 2020. Men $-53.7 \%$

$1,045 \quad$ Individuals $\geq 18$ years with confirmed COVID19, Mortality (inhospitalised in Strasbourg and Mulhouse hospital mortality) hospitals - March 2020. Average age - 66 years,

Men $-69 \%$

548 Individuals with COVID-19 admitted to Tongji Mortality (inHospital from 26 January - 5 February 2020. hospital mortality) Men $-50.9 \%$.

251 Adults $\geq 18$-years admitted between March 10 Mortality (in and April 10, 2020. Men - 51\% hospital death) 
(2020) (28) 19 outcomes.

Sourij et al. To investigate predictors of in- Austria

(2020) (29) hospital COVID- 19 mortality in patients with prediabetes and diabetes.

Wang et al. To examine the characteristics China

(2020) (30) and prognosis of COVID-19 infections

Zhang et al. To examine the influence of D- China

(2020) (31) dimer levels on COVID-19 mortality

Zhou et al. To investigate in-hospital China (2020) (9) COVID-19 risk factors.

Tartof et al. To determine the association USA

(2020) (19) between BMI and COVID-19 mortality.

Williamson To investigate risk factors of England et al. (2020) COVID-19 mortality.

average age of 54 . Men $-49.5 \%$

238

293

Adults $\geq 18$ years with laboratory-confirmed Mortality (inCOVID-19 between 12 January and 15 March hospital mortality)

15. Average age -62 years, Men $-49.3 \%$

$\geq 18$ years old adult inpatients with laboratory Mortality (inconfirmed COVID-19 from Jinyintan and hospital death) Wuhan Pulmonary Hospital. Men - 62\%

Patients with COVID-19 from 13 February - 2 Mortality (inMay 2020 from health care organisations located hospital death) throughout 9 counties in Southern California.

Men $-45 \%$ $\geq 18$ years individuals with COVID-19 and Mortality (COVIDcurrently registered as active patients in GP 19 related death) 
Grasselli et To determine risk factors Italy

al. (2020) associated with COVID-19 ICU

(17) mortalities.

Mikami et To examine factors associated USA

al. (2020) with COVID-19 mortality.

Albitar et To explore predictors of Africa

al. (2020) COVID-19 mortality among Asia patients from worldwide open America access data

Australia

Europe

$\mathrm{Wu}$ et al. To examine factors associated China

(2020) (34) with longer length of COVID-19 hospital stay

Guo et al. To investigate determinants of China

(2020) (20) COVID-19 prolonged hospital length of stay surgery. Men $-49.9 \%$

3988

6493

Patients with laboratory confirmed COVID-19 Mortality

(inwith from one of the 8 hospitals in New York hospital mortality) City metropolitan. Average age 59 years, males -

\section{$54.5 \%$}

828

COVID-19 patients with definite outcomes. Mortality)

Average age - 49.4 years, male majority -

$59.1 \%$, and majority located in Asia - 69.3\%

Patients with COVID-19 and hospitalised in LOS (number of Qiaokou Fangcang Hospital. Average age - 55.5 days spent on years, Men $-37.9 \%$

admission)

Patients with laboratory-confirmed COVID-19 LOS $\quad(<17$ days and discharged from 20 January - 16 March median Los2020. Average age -47 years, Men $-57 \%$ normal; >17days median Los prolonged) 
Mendy et To identify factors associated USA

al. (2020) with COVID-19 hospitalization

(35) and mortality among ethnically diverse cohort.
689

Patients with COVID-19 confirmed with a RT- Mortality:

PCR from the University of Cincinnati health (COVID-19 death

system between 13 March - 31 May 2020. during

Average age -49.5 years, Men $-53 \%$ hospitalisation).

LOS: (number of

days hospitalised)
241

242

243

244

245

246

247

248

249

250

251

Table 2: Synthesised review findings

\begin{tabular}{|c|c|c|c|c|}
\hline Variable category & Determinants & Variable description & $\begin{array}{l}\text { No. of studies } \\
\text { reporting sign. } \\
\text { with COVID-19 }\end{array}$ & $\begin{array}{l}\quad \text { Range of effect sizes } \\
\text { HR/OR/AOR/ } \beta \\
\text { 95\%C.I. }\end{array}$ \\
\hline
\end{tabular}




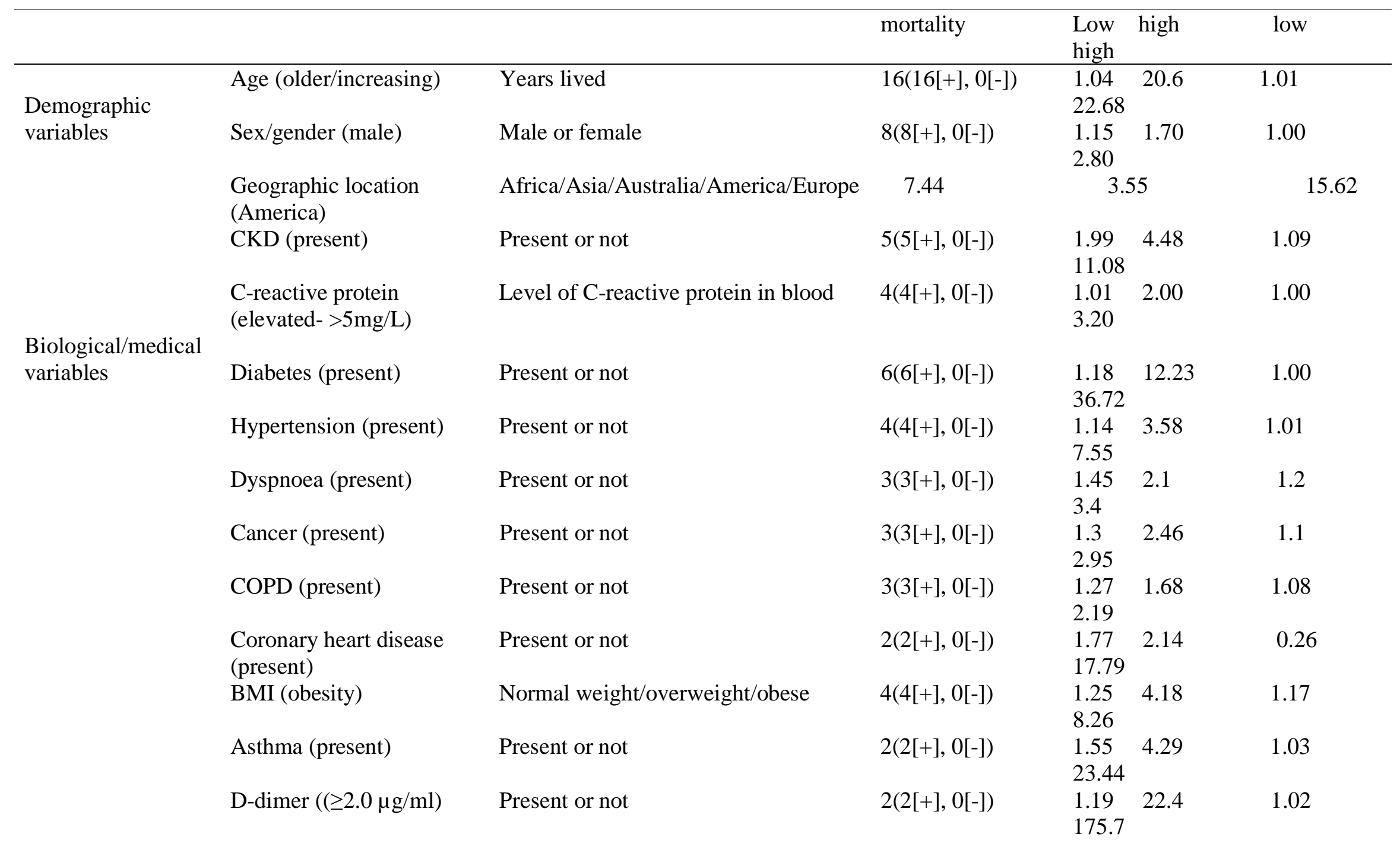




\begin{tabular}{|c|c|c|c|c|c|c|c|}
\hline & $\begin{array}{l}\text { Hospitalisation before } \\
\text { onset of COVID-19 } \\
\text { symptoms }\end{array}$ & $\begin{array}{l}\text { Time of admission relative to } \\
\text { symptom onset }\end{array}$ & \multicolumn{2}{|l|}{$1(0[+], 1[-])$} & $0.61^{0.52}$ & & 0.45 \\
\hline Lifestyle variables & Smoking (current smoker) & Smoker or non-smoker & \multicolumn{2}{|l|}{$2(2[+], 0[-])$} & $\begin{array}{l}0.8910 .09 \\
83.40\end{array}$ & & 0.28 \\
\hline $\begin{array}{l}\text { Socioeconomic } \\
\text { variables }\end{array}$ & $\begin{array}{l}\text { Index of multiple } \\
\text { deprivation (greatest) }\end{array}$ & Least to greatest & \multicolumn{2}{|l|}{$1(1[+], 0[-])$} & $\begin{array}{l}1.79 \\
1.91\end{array}$ & & 1.68 \\
\hline Variable category & Determinants & Variable description & \multirow{2}{*}{$\begin{array}{l}\text { No. of studies } \\
\text { reporting sign. with } \\
\text { COVID-19 LOS }\end{array}$} & \multicolumn{4}{|c|}{$*$ Range of effect sizes } \\
\hline & & & & \multicolumn{2}{|c|}{$\mathrm{HR} / \mathrm{OR} / \mathrm{AOR}$} & \multicolumn{2}{|c|}{ 95\%C.I } \\
\hline $\begin{array}{l}\text { Demographic } \\
\text { variables }\end{array}$ & Sex (Male) & Male or female & $2(1[+], 1[-])$ & 0.19 & 0.39 & 0.05 & 0.63 \\
\hline \multirow{6}{*}{$\begin{array}{l}\text { Biological } \\
\text { variables }\end{array}$} & Diabetes (present) & Present or not & $2(2[+], 0[-])$ & 0.50 & 3.2 & -0.2 & 0.74 \\
\hline & Fever (present) & Present or not & $2(2[+], 0[-])$ & 3.5 & 8.27 & 1.39 & 72.16 \\
\hline & $\begin{array}{l}\text { Bilateral pneumonia } \\
\text { (present) }\end{array}$ & Present or not & $1(1[+], 0[-])$ & \multicolumn{2}{|c|}{3.4} & 0.49 & 6.25 \\
\hline & CKD & Present or not & $1(1[+], 0[-])$ & \multicolumn{2}{|c|}{3.73} & 1.95 & 145.4 \\
\hline & COPD & Present or not & $1(1[+], 0[-])$ & \multicolumn{2}{|c|}{0.45} & 0.11 & 0.79 \\
\hline & Asthma & Present or not & $1(1[+], 0[-])$ & \multicolumn{2}{|c|}{0.50} & 0.20 & 0.81 \\
\hline
\end{tabular}


medRxiv preprint doi: https://doi.org/10.1101/2021.03.21.21254068; this version posted March 23, 2021. The copyright holder for this preprint (which was not certified by peer review) is the author/funder, who has granted medRxiv a license to display the preprint in perpetuity.

It is made available under a CC-BY-NC-ND 4.0 International license .

253 Age and sex were the common demographic risk factors. Of the 20 studies on age and

254 COVID-19 mortality, 16 identified increasing age as a significant determinant of COVID-19

255 mortality, with effect sizes ranging from 1.04 to 20.6 and $95 \%$ CI from 1.01 to 22.68 (9, 10,

$25611,16,17,18,24,25,26,27,28,29,30,32,33,35)$. Also, 8 of the 20 studies on gender/sex

257 and COVID-19 found men to have a higher risk of COVID-19 mortality than women (10, 11,

$25816,17,24,26,28,32)$. On LOS, 2 of the 3 studies assessing LOS found women $(\mathrm{AOR}=0.19$,

$25995 \% \mathrm{CI}=0.05-0.63)(20)$ and men $(\beta=0.39,95 \% \mathrm{CI}=0.16-0.62)(35)$ as determinants of

260 COVID-19 duration of hospitalisation.

261

262 Of biological/medical risk factors, the review identified diabetes $(n=6)$, Chronic kidney/renal

263 disease $(\mathrm{CKD})(\mathrm{n}=5)$, hypertension $(\mathrm{n}=4)$, C-reactive protein $(\mathrm{CRP})(\mathrm{n}=4)$, BMI $(\mathrm{n}=4)$,

264 dyspnoea $(n=3), \operatorname{COPD}(n=3)$, cancer $(n=3)$, coronary heart disease $(n=2)$, asthma $(n=2)$ and

265 D-dimer $(\mathrm{n}=2)$ as determinants of COVID-19 mortality. Of the 10 studies that included CKD

266 in their analysis, 5 found it a significant determinant of COVID-19 mortality $(18,25,26,30$,

267 35). Additionally, out of the 5 studies that investigated the influence of CRP on COVID-19

268 mortality, 4 showed that elevated CRP in the blood (at least $>5 \mathrm{mg} / \mathrm{L}$ ) increases the risk of

269 COVID-19 death $(11,24,26,29)$. Also, people with diabetes were found to have a higher

270 risk of COVID-19 mortality in 6 of the 18 studies on diabetes and COVID-19 mortality (16,

$271 \quad 17,18,26,30,32)$

272 Like diabetes, hypertension was also identified as a determinant of COVID-19 mortality in 4 273 out of the 16 studies $(11,16,24,30)$. Furthermore, 4 of 11 studies on BMI and COVID-19

274 mortality showed that obesity significantly determines COVID-19 mortality $(11,18,19,32)$.

275 For LOS, fever and diabetes were associated with prolonged LOS $(43,35)$.

276 
medRxiv preprint doi: https://doi.org/10.1101/2021.03.21.21254068; this version posted March 23, 2021. The copyright holder for this preprint (which was not certified by peer review) is the author/funder, who has granted medRxiv a license to display the preprint in perpetuity.

It is made available under a CC-BY-NC-ND 4.0 International license .

277 On lifestyle factors, smoking was the only assessed determinant of COVID-19 outcomes. It 278 was identified as a risk factor for COVID-19 mortality in 2 of the eleven studies that explored 279 it, with effect size ranging from $0.89-10.09,95 \%$ CIs from $0.28-83.40(23,32)$. None of the 280 studies on LOS reported a significant association between smoking and COVID-19 LOS.

281 Finally, the only study on socioeconomic determinants and COVID-19 reported that greater 282 deprivation determines COVID-19 mortality (HR=1.79, 95\%1.68 - 1.91) (32)

\section{Discussion}

This review aimed to investigate the determinants of COVID-19 outcomes. The review found that the specification and subsequent analysis of most of the determinants differed across the studies. For example, Berenguer et al. (2020) described elevated C-reactive protein (CRP) as

291 CRP>5mg/L, while Carrasco-Sánchez et al. (2020) described it as >60mg/L. Also, whilst 292 Almazeedi et al. (2020) and Sourij et al. (2020) assessed CRP as a continuous variable, 293 Kaeuffer et al. (2020) categorised it into two groups: CRP- 100-199mg/L and CRP $\geq 200 \mathrm{mg} / \mathrm{L}$. 294 Like CRP, older age was also specified differently across the studies. Bello-Chavolla et al. 295 (2020) and Li et al. (2020) described it as individuals $\geq 65$ years, Zhang et al. (2020) termed it 296 as persons $>65$ years while Petrilli et al. (2020) defined it as people $\geq 75$ years. Apart from 297 these variations, the study settings also differed across the papers. These contextual 298 differences, which could include disparities in access to healthcare, crowded living, could 299 have inherently influenced the studies' findings (36).

300 Despite these heterogeneities, the result of some of the determinants was similar across the 301 studies. For instance, the significant association between age and COVID-19 mortality was 
medRxiv preprint doi: https://doi.org/10.1101/2021.03.21.21254068; this version posted March 23, 2021. The copyright holder for this preprint (which was not certified by peer review) is the author/funder, who has granted medRxiv a license to display the preprint in perpetuity.

It is made available under a CC-BY-NC-ND 4.0 International license .

reported across sixteen out of twenty papers, and four out of five articles examining CRP also showed a significant association between CRP and COVID-19 mortality. Regardless of the differences in methods, these findings could have public health implications for populations worldwide (37). Thus, they can be considered during the planning and implementation of effective policies for COVID-19.

Nonetheless, there were other contrasting findings. For example, Mendy et al. (2020) indicated that men are more likely to stay longer in hospitals due to COVID-19 than women. Conversely, Guo et al. (2020) showed that women are more associated with prolonged COVID-19 hospitalisation than men. Both studies had men dominating their study participants, 53\% and 57\% respectively; but the proportion of men in Guo et al. (2020) were marginally higher. However, in absolute figures, Mendy et al. (2020) included more male participants $(n=365)$ than Guo et al. $(2020)(n=43)$. Therefore, these sample size variations could account for the differences in their sex and LOS findings due to COVID-19. Moreover, these findings are from only two studies; thus, they may not be enough to conclude the association between sex and COVID-19 LOS. Further discussions on the review findings, based on the determinants of health model, are provided below.

\section{Demographic determinants of COVID-19 outcomes}

The underlying mechanism for the association between older age and COVID-19 mortality is unclear; however, several studies indicate that decrease in immune responses coupled with increase comorbid burden with ageing may account for this observation $(9,38,39)$. Another study further explained that age-related changes or defects in the immune system, particularly significant defect in cell-mediated immunity, primarily affects immune responses to diseases (40). Also, evolution and ageing theories, like the antagonistic pleiotropy theory, postulate that even beneficial genes at an early age may be less efficient or deleterious with increasing 
medRxiv preprint doi: https://doi.org/10.1101/2021.03.21.21254068; this version posted March 23, 2021. The copyright holder for this preprint (which was not certified by peer review) is the author/funder, who has granted medRxiv a license to display the preprint in perpetuity.

It is made available under a CC-BY-NC-ND 4.0 International license .

327 age, and this may inherently increase susceptibility to previously shielded diseases $(41,42)$.

328 Moreover, current evidence suggests that increasing age is a common risk factor for several

329 health outcomes, like mortalities and morbidities (43-46).

331 Even though ageing generally decreases immune responses to diseases and infections, the 332 innate human response is mostly safeguarded (40). Thus, many individual and environmental 333 factors may account for the relationship between ageing and disease outcomes, such as 334 COVID-19 mortality. These factors may include nutritional deficiencies, decreased 335 functionality, exposure to pathogens, vaccinations, an individual's lived experiences and 336 genetic make-up and access to health care (47). Furthermore, there are reports on good 337 COVID-19 prognosis in elderly patients (48). Therefore, it may be imperative to understand 338 how these factors cumulatively affect the immune system, and further mediate ageing and decreased immune system relationship to provide exhaustive literature on the subject. Other 340 studies have also reported severe COVID-19 consequences in children (49, 50). 341 Consequently, there is a need for studies to focus more on children, as much as they have on the adult population to offer a balanced argument to inform COVID-19 and ageing policies.

344 Like ageing, studies also attribute the sex disparities regarding COVID-19 mortality to sex345 based differences in immunological responses to viral infections $(51,52)$. The $X$ sex 346 chromosome has encoded immune regulatory genes that decrease viral infections' 347 susceptibility (51). Since women have twice X-chromosomes to men, they tend to have 348 higher innate immunity to viral infections, like COVID-19, and by extension a lower risk of severe COVID-19 outcomes than men $(51,53)$. Similarly, in contrast to oestrogen, 350 testosterone has an immunosuppressive effect; so, it attenuates men's immune responses to 351 viral infections (54). Additionally, it is reported that men are genetically more predisposed to 
medRxiv preprint doi: https://doi.org/10.1101/2021.03.21.21254068; this version posted March 23, 2021. The copyright holder for this preprint (which was not certified by peer review) is the author/funder, who has granted medRxiv a license to display the preprint in perpetuity.

It is made available under a CC-BY-NC-ND 4.0 International license .

352 produce higher levels interleukin (IL)-6, which are unfavourable to longevity, compared to 353 women (55). Apart from these biological reasons accounting for the sex differences in 354 COVID-19 mortality risk, behavioural and lifestyle factors like smoking and alcohol 355 consumption, have been implicated in the gender disparities in COVID-19 outcomes. Data 356 indicate that men are more likely to engage in these lifestyle factors that increase the risk of 357 COVID-19 deaths than women (52). Women are more likely to comply with COVID-19 358 precautionary measures than men and are more likely to remain confined than men (56). 359 Regarding LOS, the evidence is not enough to indicate whether sex determines longer COVID-19 hospitalisation.

\section{Biological/medical determinants of COVID-19 outcomes}

The biological/medical determinants in this review were comorbidities, symptoms, and laboratory findings of the included studies participants. The biological determinants of COVID-19 outcomes included CKD, C-reactive protein, diabetes, hypertension, obesity, cancer, COPD, dyspnea, asthma, and coronary heart disease. Clinical data reveal that chronic conditions, such as the above, decrease innate immune responses in humans $(57,58)$. For instance, metabolic diseases/disorders, like diabetes, attenuates immunity and increase risk to infections by weakening lymphocyte and macrophage activities (59). Moreover, these chronic conditions are associated with increase pro-inflammatory cytokines resulting from dysregulation of systems, like the hypothalamic-pituitary-adrenal and sympathetic nervous system $(58,60)$. The accumulation of pro-inflammatory cytokines subsequently impairs systemic and cellular immune functions $(57,61)$. 
medRxiv preprint doi: https://doi.org/10.1101/2021.03.21.21254068; this version posted March 23, 2021. The copyright holder for this preprint (which was not certified by peer review) is the author/funder, who has granted medRxiv a license to display the preprint in perpetuity.

It is made available under a CC-BY-NC-ND 4.0 International license .

375 Furthermore, studies hypothesize that the use of renin-angiotensin-aldosterone system

376 (RAAS) inhibitors, like angiotensin-converting enzyme-2 (ACE-2), in the management of

377 some of these chronic conditions increase COVID-19 infectivity $(62,63)$. This is because

378 ACE2 also functions as a receptor for the COVID-19 virus (64). This RAAS and ACE-2

379 hypothesis recently sparked debate and discourse on gold standard medical management of

380 comorbidities in COVID-19 patients. One study indicated that sudden discontinuation of

381 ACE-2 might have far worse consequences for high-risk-COVID-19 patients, particularly

382 those with cardiovascular conditions, like myocardial infarction (65). Their argument is

383 hinged on the paucity of human studies to corroborate the RAAS and ACE-2 theory.

384 Additionally, experimental studies in mice showed that ACE-2 downregulation facilitates

385 lung injuries and increases viral loads $(60,66)$. Thus, several human studies are needed to

386 substantiate the harmful effect, or otherwise, of RAAS inhibitors in the management of

387 COVID-19 patients with comorbidities.

389 Lifestyle determinants of COVID-19 outcomes

390 The included studies examined only smoking as a lifestyle determinant of COVID-19 391 mortality. The association between smoking and COVID-19 mortality is biologically 392 plausible because smoking is a risk factor for several conditions, like coronary heart disease and Chronic Obstructive Pulmonary Disease (COPD), that are associated with severe COVID-19 outcomes (67). Also, a cohort study with an average of 9.6 years follow-up by showed that $11 \%$ (men) and 13\% (women) of pneumonia and COPD deaths were attributable to smoking (68). Additionally, the Centre for Disease Control and Prevention (CDC) also report that smoking is associated with about 113,000 respiratory deaths each year in the

398 United States (69). Since COVID-19 is a respiratory infection and based on the above 
medRxiv preprint doi: https://doi.org/10.1101/2021.03.21.21254068; this version posted March 23, 2021. The copyright holder for this preprint (which was not certified by peer review) is the author/funder, who has granted medRxiv a license to display the preprint in perpetuity.

It is made available under a CC-BY-NC-ND 4.0 International license .

evidence on smoking-related respiratory deaths, it may be reasonable to make projections that smoking may be significantly associated with severe COVID-19 outcomes.

Furthermore, data shows that smokers have increased upregulation or expression of ACE-2, the reported enzyme receptor for SARS-CoV-2 (COVID-19) (70), which may increase their risk of severe COVID-19 outcomes compared to non-smokers. A single-cell sequencing experiment further demonstrated that cigarette smoking upregulates ACE-2 in humans' lungs and increases their susceptibility to COVID-19 infections (71). They inferred that smoking cessation could reduce ACE- 2 expression and thereby reduce the risk of COVID-19 disease. Thus, their findings advance the above argument on the benefit or otherwise of ACE-2 dysregulation in humans in reducing the burden of COVID-19. Consequently, systematic reviews and meta-analyses of several high-quality studies on ACE-2 and COVID-19 are required to provide empirical evidence to inform policy and clinical practice. All the same, this review is limited in drawing a meaningful conclusion on the association between smoking and COVID-19 mortality because only one of the included studies identified smoking as a risk factor of COVID-19 mortality.

\section{Policy implications}

This review findings re-enforce the need for health systems to continue the testing, tracing, and isolation policies to reduce the spread of the virus and subsequently decrease the burden of the pandemic, particularly for high-risk individuals identified in this review. Additionally, countries, such as Nigeria, that are yet to implement crucial public health policies, like immunisation and routine COVID-19 testing, can draw lessons from countries like the UK that have benefited immensely from such policies. Although this may come with increased direct costs, especially the cost of PPEs and testing equipment, the indirect benefits to 
medRxiv preprint doi: https://doi.org/10.1101/2021.03.21.21254068; this version posted March 23, 2021. The copyright holder for this preprint (which was not certified by peer review) is the author/funder, who has granted medRxiv a license to display the preprint in perpetuity.

It is made available under a CC-BY-NC-ND 4.0 International license .

423 populations, such as reduced disease burden and improved productivity, might be enormous

424 for these countries.

425 However, lockdown policies, which seems to be the go-to policy for most countries, must be 426 evaluated holistically, to ascertain their overall benefits, especially as the pandemic continues

427 to rage. Evidence shows that lockdowns are beneficial when introduced at an earlier stage of 428 an outbreak than later. For example, evaluating the national lockdown response in Norway, 429 USA, Argentina, and the UK shows that the lockdown's timing and not the lockdown itself 430 significantly reduced the burden of the outbreak in Argentina and Norway compared to the 431 UK and the USA. For instance, the UK suffered significant health and economic recession 432 due to the delays in the lockdown response to the viral outbreak. Their delay in implementing 433 the first lockdown resulted in several other lockdowns that have had further economic 434 implications. Therefore, lockdowns must be implemented earlier to prevent dire health and economic consequences.

436 Even the timing of lockdowns alone may not be enough to radically reduce viral transmission

437 rate and consequently limit the probability of infections in high-risk individuals because data

438 from other jurisdictions that introduced earlier national lockdowns, like Ghana, showed a 439 steady increase in transmissions during the lockdown and a rapid rise few weeks post 440 lockdown. Also, it is still crippling with the lockdown induced economic downfall. This 441 suggests that lockdowns as single policies may be ineffective in plummeting COVID-19 442 infections, mortalities, and financial hardships. Consequently, global health systems must 443 also place a premium on other equally important policies, like robust testing and tracing. 444 Currently, most countries do not conduct follow-up COVID-19 testing following negative 445 test results at entry borders. A negative test result on arrival at entry borders may not be enough to declare individuals as virus-free since it can take fourteen days maximum for the virus to be detected, per the WHO guidelines. Thus, governments must apply both on arrival 
medRxiv preprint doi: https://doi.org/10.1101/2021.03.21.21254068; this version posted March 23, 2021. The copyright holder for this preprint (which was not certified by peer review) is the author/funder, who has granted medRxiv a license to display the preprint in perpetuity.

It is made available under a CC-BY-NC-ND 4.0 International license .

448 and fourteen days post border arrival COVID-19 testing to ensure comprehensive

449 identification of all positive cases to curtail the virus's potential spread.

450 Additionally, it will be crucial for countries, like the USA and Brazil, to implement the

451 fourteen-day quarantine policies for all border entries, as it has shown to be effective 452 reducing the COVID-19 impact in places like Argentina. Countries with partial quarantine 453 policies, such as Ghana, will benefit from instituting mandatory quarantine for all border 454 arrivals at government selected facilities since self-isolation education and passenger locator 455 forms may be inadequate in reducing the viral spread. Furthermore, health systems must 456 continuously promote behavioural change interventions to establish significant control over 457 the viral outbreak. Enforcing compliance to behavioural change interventions, like social 458 distancing, nose mask use, social hand washing and cough etiquette, can be the significant 459 catalyst needed to decrease the pandemic's impact. Finally, the continuous increase in the 460 COVID-19 cases and mortality indicate the need for an urgent review of current health 461 policies at both international and national levels to implement suitable context-specific 462 interventions to mitigate the COVID-19 menace effectively.

464 Concerning this study's strength, this is the first systematic review synthesising the evidence on LOS determinants, to the best of the researchers' knowledge. Therefore, it presents novel

466 findings that could initiate useful interventions to address the burden of prolonged 467 hospitalisation associated with COVID-19. It could also cause a paradigm shift and ensure 468 holistic research coverage on all COVID-19 outcomes. Moreover, this is the first review to 469 provide a comprehensive investigation of contextual determinants of COVID-19 outcomes, 470 based on the determinants of health model. It identified crucial gaps in the literature on the 471 determinants of COVID-19 outcomes that require urgent attention. Additionally, this review 
medRxiv preprint doi: https://doi.org/10.1101/2021.03.21.21254068; this version posted March 23, 2021. The copyright holder for this preprint (which was not certified by peer review) is the author/funder, who has granted medRxiv a license to display the preprint in perpetuity.

It is made available under a CC-BY-NC-ND 4.0 International license .

472 evaluated current public health policies and suggested strategies to augment area-specific

473 efforts at curbing the COVID-19 problem. Regarding limitations, the review was restricted in

474 conducting further analysis, specifically, meta-analysis, to precisely estimate the associations'

475 effect size due to included studies' heterogeneity. Also, most of the included studies ( $\mathrm{n}=12)$

476 used retrospective design, thus, there was the possibility of residual confounders that could

477 influence this review's findings. Additionally, all of them used secondary data from medical

478 records of participants. Therefore, any omission or data entry error could affect their results

479 and this review. Hence, caution must be taken when interpreting the findings of this review.

\section{Conclusion and recommendations}

483 This study's overarching aim was to examine the determinants of COVID-19 outcomes. The

484 review findings showed that increasing age and comorbidities are more likely to determine 485 COVID-19 outcomes. Thus, policies, like routine COVID-19 testing and prioritised 486 vaccination to shield these high-risk individuals, must be sustained and extended to other 487 populations yet to implement such important policies. Most importantly, health systems must 488 continually review existing policies to ensure their context-specific relevance, especially with 489 the emergence of a new viral variant and the rapid surge in cases. Based on this review, the 490 authors recommend that future studies also focus on determinants of COVID-19 LOS. 491 Additionally, studies should explore the determinants of COVID-19 outcomes in low492 income-countries to ensure holistic and context-specific evidence on risk factors of COVID49319 mortality in the literature. 
medRxiv preprint doi: https://doi.org/10.1101/2021.03.21.21254068; this version posted March 23, 2021. The copyright holder for this preprint (which was not certified by peer review) is the author/funder, who has granted medRxiv a license to display the preprint in perpetuity.

It is made available under a CC-BY-NC-ND 4.0 International license .

1. WHO. Coronavirus Disease (COVID-19) Dashboard. 2021. Available from: https://covid19.who.int/. (Accessed on 10/01/2021).

2. Azamfirei R. The 2019 novel coronavirus: a crown jewel of pandemics? The Journal of Critical Care Medicine. 2020 Jan 31;6(1):3-4.

3. Nishiura H, Kobayashi T, Miyama T, Suzuki A, Jung SM, Hayashi K. et al. Estimation of the asymptomatic ratio of novel coronavirus infections (COVID-19). International journal of infectious diseases. 2020 May; 94:154.

4. Yuan J, Li M, Lv G, Lu ZK. Monitoring transmissibility and mortality of COVID-19 in Europe. International Journal of Infectious Diseases. 2020 Jun 1; 95:311-5. https://doi.org/10.1016/j.ijid.2020.03.050.

5. Promislow DE. A geroscience perspective on COVID-19 mortality. The Journals of $\begin{array}{lllll}\text { Gerontology: } & \text { Series } & \text { A. } & 2020 & \text { Sep;75(9): }\end{array}$ https://doi.org/10.1093/gerona/glaa094.

6. Maia Chagas A, Molloy JC, Prieto-Godino LL, Baden T. Leveraging open hardware to alleviate the burden of COVID-19 on global health systems. PLoS biology. 2020 Apr 24;18(4): e3000730.

7. Ornell F, Schuch JB, Sordi AO, Kessler FH. "Pandemic fear" and COVID-19: mental health burden and strategies. Brazilian Journal of Psychiatry. 2020 Jun;42(3):232-5.

8. Amponsah R, Frimpong IA. Ghana in the Face of COVID-19: Economic Impact of Coronavirus (2019-NCOV) Outbreak on Ghana. Open Journal of Business and $\begin{array}{lllll}\text { Management. } & 2020 & \text { Jun } & 17 ; 8(04): & \end{array}$ http://www.scirp.org/journal/Paperabs.aspx?PaperID=100937.

9. Zhou F, Yu T, Du R, Fan G, Liu Y, Liu Z. et al. Clinical course and risk factors for mortality of adult inpatients with COVID-19 in Wuhan, China: a retrospective cohort study. The lancet. 2020 Mar 28;395(10229):1054-62.

10. Li X, Xu S, Yu M, Wang K, Tao Y, Zhou Y. et al. Risk factors for severity and mortality in adult COVID-19 inpatients in Wuhan. Journal of Allergy and Clinical Immunology. 2020 Jul 1;146(1):110-8. 
medRxiv preprint doi: https://doi.org/10.1101/2021.03.21.21254068; this version posted March 23, 2021. The copyright holder for this preprint (which was not certified by peer review) is the author/funder, who has granted medRxiv a license to display the preprint in perpetuity.

It is made available under a CC-BY-NC-ND 4.0 International license.

11. Berenguer J, Ryan P, Rodríguez-Baño J, Jarrín I, Carratalà J, Pachón J. et al. Characteristics and predictors of death among 4035 consecutively hospitalized patients with COVID-19 in Spain. Clinical Microbiology and Infection. 2020 Nov $1 ; 26(11): 1525-36$.

12. Sepandi M, Taghdir M, Alimohamadi Y, Afrashteh S, Hosamirudsari H. Factors Associated with Mortality in COVID-19 Patients: A Systematic Review and MetaAnalysis. Iranian journal of public health. 2020; 49(7), 1211-1221.

13. Mesas AE, Cavero-Redondo I, Álvarez-Bueno C, Sarriá Cabrera MA, Maffei de Andrade S, Sequí-Dominguez I. et al. Predictors of in-hospital COVID-19 mortality: A comprehensive systematic review and meta-analysis exploring differences by age, sex and health conditions. PloS one. 2020 Nov 3;15(11): e0241742

14. Zeng X, Zhang Y, Kwong JS, Zhang C, Li S, Sun F. et al. The methodological quality assessment tools for preclinical and clinical studies, systematic review and meta $\square$ analysis, and clinical practice guideline: a systematic review. Journal of evidence-based medicine. 2015 Feb;8(1):2-10

15. Aromataris E, Munn Z (Editors). JBI Manual for Evidence Synthesis. JBI, 2020. Available from https://synthesismanual.jbi.global. https://doi.org/10.46658/JBIMES20-01.\#.

16. Albitar O, Ballouze R, Ooi JP, Ghadzi SM. Risk factors for mortality among COVID19 patients. Diabetes research and clinical practice. 2020 Aug 1; 166:108293.

17. Grasselli G, Greco M, Zanella A, Albano G, Antonelli M, Bellani G. et al. Risk factors associated with mortality among patients with COVID-19 in intensive care units in Lombardy, Italy. JAMA internal medicine. 2020 Oct 1;180(10):1345-55.

18. Bello-Chavolla OY, Bahena-López JP, Antonio-Villa NE, Vargas-Vázquez A, González-Díaz A, Márquez-Salinas A. et al. Predicting mortality due to SARS-CoV2: A mechanistic score relating obesity and diabetes to COVID-19 outcomes in Mexico. The Journal of Clinical Endocrinology \& Metabolism. 2020 Aug;105(8):2752-61.

19. Tartof SY, Qian L, Hong V, Wei R, Nadjafi RF, Fischer H. et al. Obesity and mortality among patients diagnosed with COVID-19: results from an integrated health care organization. Annals of internal medicine. 2020 Nov 17;173(10):773-81.

20. Guo A, Lu J, Tan H, Kuang Z, Lou Y, Yang T. et al. Risk Factors on Admission Associated with Hospital Length of Stay in Patients with COVID-19: A Retrospective Cohort Study. Available at SSRN 3582769. 2020 Apr 20. 
medRxiv preprint doi: https://doi.org/10.1101/2021.03.21.21254068; this version posted March 23, 2021. The copyright holder for this preprint (which was not certified by peer review) is the author/funder, who has granted medRxiv a license to display the preprint in perpetuity.

It is made available under a CC-BY-NC-ND 4.0 International license .

21. Dahlgren G., Whitehead M. Tackling social inequalities in health. 1993. Available from: https://www.euro.who.int/ data/assets/pdf file/0018/103824/E89384.pdf.

22. Alaa A, Qian Z, Rashbass J, Benger J, van der Schaar M. Retrospective cohort study of admission timing and mortality following COVID-19 infection in England. BMJ open. 2020 Nov 1;10(11):e042712.

23. Almazeedi S, Al-Youha S, Jamal MH, Al-Haddad M, Al-Muhaini A, Al-Ghimlas F. et al. Characteristics, risk factors and outcomes among the first consecutive 1096 patients diagnosed with COVID-19 in Kuwait. EClinicalMedicine. 2020 Jul 1; 24:100448.

24. Carrasco-Sánchez FJ, López-Carmona MD, Martínez-Marcos FJ, Pérez-Belmonte LM, Hidalgo-Jiménez A, Buonaiuto V. et al. Admission hyperglycaemia as a predictor of mortality in patients hospitalized with COVID-19 regardless of diabetes status: data from the Spanish SEMI-COVID-19 Registry. Annals of medicine. 2021 Jan 1;53(1):103-16.

25. Halalau A, Imam Z, Karabon P, Mankuzhy N, Shaheen A, Tu J. et al. External validation of a clinical risk score to predict hospital admission and in-hospital mortality in COVID-19 patients. Annals of medicine. 2021 Jan 1;53(1):78-86.

26. Kaeuffer C, Le Hyaric C, Fabacher T, Mootien J, Dervieux B, Ruch Y. et al. Clinical characteristics and risk factors associated with severe COVID-19: prospective analysis of 1,045 hospitalised cases in North-Eastern France, March 2020. Eurosurveillance. 2020 Dec 3;25(48):2000895.

27. Okoh AK, Sossou C, Dangayach NS, Meledathu S, Phillips O, Raczek C. et al. Coronavirus disease 19 in minority populations of Newark, New Jersey. International journal for equity in health. 2020 Dec;19(1):1-8.

28. Petrilli CM, Jones SA, Yang J, Rajagopalan H, O’Donnell L, Chernyak Y. et al. Factors associated with hospital admission and critical illness among 5279 people with coronavirus disease 2019 in New York City: prospective cohort study. Bmj. 2020 May 22;369.

29. Sourij H, Aziz F, Bräuer A, Ciardi C, Clodi M, Fasching P. et al. COVID $\square 19$ fatality prediction in people with diabetes and prediabetes using a simple score upon hospital admission. Diabetes, Obesity and Metabolism. 2020 Nov 16.

30. Wang Z, Ye D, Wang M, Zhao M, Li D, Ye J. et al. Clinical Features of COVID-19 Patients with Different Outcomes in Wuhan: A Retrospective Observational Study. BioMed research international. 2020 Oct 5;2020. 
medRxiv preprint doi: https://doi.org/10.1101/2021.03.21.21254068; this version posted March 23, 2021. The copyright holder for this preprint (which was not certified by peer review) is the author/funder, who has granted medRxiv a license to display the preprint in perpetuity.

It is made available under a CC-BY-NC-ND 4.0 International license .

595

596

597

598

599

600

601

602

603

604

605

606

607

608

609

610

611

612

613

614

615

616

617

618

619

620

621

622

623

624

625

626

627

31. Zhang L, Yan X, Fan Q, Liu H, Liu X, Liu Z. et al. D $\square$ dimer levels on admission to predict in $\square$ hospital mortality in patients with Covid $\square$ 19. Journal of Thrombosis and Haemostasis. 2020 Jun;18(6):1324-9.

32. Williamson EJ, Walker AJ, Bhaskaran K, Bacon S, Bates C, Morton CE. et al. OpenSAFELY: factors associated with COVID-19 death in 17 million patients. Nature. 2020 Jul 8; 584(7821):430-436. DOI: 10.1038/s41586-020-2521-4

33. Mikami T, Miyashita H, Yamada T, Harrington M, Steinberg D, Dunn A. et al. Risk factors for mortality in patients with COVID-19 in New York City. Journal of general internal medicine. 2020 Jun 30:1-0.

34. Wu S, Xue L, Legido-Quigley H, Khan M, Wu H, Peng X. et al. Understanding factors influencing the length of hospital stay among non-severe COVID-19 patients: A retrospective cohort study in a Fangcang shelter hospital. Plos one. 2020 Oct 21;15(10): e0240959.

35. Mendy A, Apewokin S, Wells AA, Morrow AL. Factors associated with hospitalization and disease severity in a racially and ethnically diverse population of COVID-19 patients. MedRxiv. 2020 Jan 1.

36. van Bavel JJ, Mende-Siedlecki P, Brady WJ, Reinero DA. Contextual sensitivity in scientific reproducibility. Proceedings of the National Academy of Sciences. 2016 Jun; 113 (23) 6454-6459; DOI: 10.1073/pnas.1521897113

37. Ioannidis JP, Axfors C, Contopoulos-Ioannidis DG. Population-level COVID-19 mortality risk for non-elderly individuals overall and for non-elderly individuals without underlying diseases in pandemic epicenters. Environmental research. 2020 Sep 1; 188:109890.

38. Mueller AL, McNamara MS, Sinclair DA. Why does COVID-19 disproportionately affect older people? Aging (Albany NY). 2020 May 31;12(10):9959.

39. Chinnadurai R, Ogedengbe O, Agarwal P, et al. Older age and frailty are the chief predictors of mortality in COVID-19 patients admitted to an acute medical unit in a secondary care setting- a cohort study. BMC Geriatrics. 2020 Oct;20(1):409. DOI: 10.1186/s12877-020-01803-5.

40. Opal SM, Girard TD, Ely EW. The immunopathogenesis of sepsis in elderly patients. Clinical infectious diseases. 2005 Nov 15;41(Supplement_7): S504-12.

41. Mitteldorf J. What is antagonistic pleiotropy? Biochemistry (Moscow). 2019 Dec;84(12):1458-68. https://doi.org/10.1134/S0006297919120058 
medRxiv preprint doi: https://doi.org/10.1101/2021.03.21.21254068; this version posted March 23, 2021. The copyright holder for this preprint (which was not certified by peer review) is the author/funder, who has granted medRxiv a license to display the preprint in perpetuity.

It is made available under a CC-BY-NC-ND 4.0 International license .

42. Williams PD, Day T. Antagonistic pleiotropy, mortality source interactions, and the evolutionary theory of senescence. Evolution. 2003 Jul;57(7):1478-88.

43. Australian Institute of Health. Social Distribution of Health Risks and Health Outcomes: Preliminary Analysis of the National Health Survey 2007-08. AIHW; 2012.

44. Eguchi T, Bains S, Lee MC, Tan KS, Hristov B, Buitrago DH. et al. Impact of increasing age on cause-specific mortality and morbidity in patients with stage I nonsmall-cell lung cancer: a competing risks analysis. Journal of Clinical Oncology. 2017 Jan 20;35(3):281.

45. Johansson S, Rosengren A, Young K, Jennings E. Mortality and morbidity trends after the first year in survivors of acute myocardial infarction: a systematic review. BMC Cardiovascular Disorders. 2017 Dec;17(1):1-8.

46. Niccoli T, Partridge L. Ageing as a risk factor for disease. Current biology. 2012 Sep 11;22(17): R741-52.

47. Hernández DS, Verdecia BG. Immunosenescence: effects of aging process on immune system. Revista Cubana de Hematología, Inmunología y Hemoterapia. 2014;30(4):332-45.

48. Ma Y, Hou L, Yang X, Huang Z, Yang X, Zhao N. et al. The association between frailty and severe disease among COVID-19 patients aged over 60 years in China: a prospective cohort study. BMC medicine. 2020 Dec;18(1):1-8.

49. Liu J, Zhang S, Wu Z, Shang Y, Dong X, Li G. et al. Clinical outcomes of COVID-19 in Wuhan, China: a large cohort study. Annals of intensive care. 2020 Dec;10(1):1-21.

50. Qiu H, Wu J, Hong L, Luo Y, Song Q, Chen D. Clinical and epidemiological features of 36 children with coronavirus disease 2019 (COVID-19) in Zhejiang, China: an observational cohort study. The Lancet Infectious Diseases. 2020 Jun 1;20(6):689-96.

51. Conti P, Younes A. Coronavirus COV-19/SARS-CoV-2 affects women less than men: clinical response to viral infection. J Biol Regul Homeost Agents. 2020 Apr 7;34(2):339-43.

52. Bwire GM. Coronavirus: why men are more vulnerable to Covid-19 than women?. SN comprehensive clinical medicine. 2020 Jul;2(7):874-6. https://doi.org/10.1007/s42399-020-00341-w.

53. Elgendy IY, Pepine CJ. Why are women better protected from COVID-19: Clues for men? Sex and COVID-19. International journal of cardiology. 2020 Sep 15; 315:1056. 
medRxiv preprint doi: https://doi.org/10.1101/2021.03.21.21254068; this version posted March 23, 2021. The copyright holder for this preprint (which was not certified by peer review) is the author/funder, who has granted medRxiv a license to display the preprint in perpetuity.

It is made available under a CC-BY-NC-ND 4.0 International license.

54. Pradhan A, Olsson PE. Sex differences in severity and mortality from COVID-19: are males more vulnerable?. Biology of sex Differences. 2020 Dec;11(1):1-1.

55. Marcon G, Tettamanti M, Capacci G, Fontanel G, Spanò M, Nobili A. et al. COVID19 mortality in Lombardy: the vulnerability of the oldest old and the resilience of male centenarians. Aging (Albany NY). 2020 Aug 15;12(15):15186.

56. De La Vega R, Ruíz-Barquín R, Boros S, Szabo A. Could attitudes toward COVID-19 in Spain render men more vulnerable than women? Global public health. 2020 Sep $1 ; 15(9): 1278-91$.

57. Odegaard JI, Chawla A. Connecting type 1 and type 2 diabetes through innate immunity. Cold Spring Harbor perspectives in medicine. 2012 Mar 1;2(3): a007724.

58. Schulkin J, editor. Allostasis, homeostasis, and the costs of physiological adaptation. Cambridge University Press; 2004 Oct 25.

59. Oates JR, McKell MC, Moreno-Fernandez ME, Damen MS, Deepe Jr GS, Qualls JE. et al. Macrophage function in the pathogenesis of non-alcoholic fatty liver disease: the mac attack. Frontiers in immunology. 2019 Dec 12; 10:2893.

60. Yang P, Gu H, Zhao Z, Wang W, Cao B, Lai C. et al. Angiotensin-converting enzyme 2 (ACE2) mediates influenza H7N9 virus-induced acute lung injury. Scientific reports. 2014 Nov 13;4(1):1-6.

61. McEwen BS. Sex, stress and the hippocampus: allostasis, allostatic load and the aging process. Neurobiology of aging. 2002 Sep 1;23(5):921-39.

62. Ferrario CM, Jessup J, Chappell MC, Averill DB, Brosnihan KB, Tallant EA. et al. Effect of angiotensin-converting enzyme inhibition and angiotensin II receptor blockers on cardiac angiotensin-converting enzyme 2. Circulation. 2005 May 24;111(20):2605-10.

63. Watkins J. Preventing a covid-19 pandemic. BMJ. 2020;368:m810. https://doi.org/10.1136/bmj.m810.

64. Hoffmann M, Kleine-Weber H, Schroeder S, Krüger N, Herrler T, Erichsen S. et al. SARS-CoV-2 cell entry depends on ACE2 and TMPRSS2 and is blocked by a clinically proven protease inhibitor. cell. 2020 Apr 16;181(2):271-80.

65. Vaduganathan M, Vardeny O, Michel T, McMurray JJ, Pfeffer MA, Solomon SD. Renin-angiotensin-aldosterone system inhibitors in patients with Covid-19. New England Journal of Medicine. 2020 Apr 23;382(17):1653-9. 
medRxiv preprint doi: https://doi.org/10.1101/2021.03.21.21254068; this version posted March 23, 2021. The copyright holder for this preprint (which was not certified by peer review) is the author/funder, who has granted medRxiv a license to display the preprint in perpetuity.

It is made available under a CC-BY-NC-ND 4.0 International license .

695

696

697

698

699

700

701

702

703

704

705

706

707

708

709

710

711

712

713

714

715

716

717

718

719

720

721

722

723

724

725

726
66. Kuba K, Imai Y, Rao S, Gao H, Guo F, Guan B. et al. A crucial role of angiotensin converting enzyme 2 (ACE2) in SARS coronavirus-induced lung injury. Nature medicine. 2005 Aug;11(8):875-9.

67. Reddy RK, Charles WN, Sklavounos A, Dutt A, Seed PT, Khajuria A. The effect of smoking on COVID $\square 19$ severity: A systematic review and meta $\square$ analysis. Journal of Medical Virology. 2021 Feb;93(2):1045-56.

68. Katanoda K, Marugame T, Saika K, Satoh H, Tajima K, Suzuki T. et al. Population attributable fraction of mortality associated with tobacco smoking in Japan: a pooled analysis of three large-scale cohort studies. Journal of epidemiology. 2008:0812050049-.

69. Centre for Disease Control and Prevention. Tobacco related Mortality. 2020. Available

from: https://www.cdc.gov/tobacco/data statistics/fact sheets/health effects/tobacco relate d mortality/index.htm

70. Leung JM, Yang CX, Tam A, Shaipanich T, Hackett TL, Singhera GK. et al. ACE-2 expression in the small airway epithelia of smokers and COPD patients: implications for COVID-19. European Respiratory Journal. 2020 May 1;55(5).

71. Smith JC, Sausville EL, Girish V, Yuan ML, Vasudevan A, John KM, Sheltzer JM. Cigarette smoke exposure and inflammatory signalling increase the expression of the SARS-CoV-2 receptor ACE2 in the respiratory tract. Developmental cell. 2020 Jun 8;53(5):514-29.

72. Park J, Lee Y, Seo H, Jang B, Son H, Kim S, Shin S, Hahn S. Risk of Bias Assessment tool for Non-randomized Studies (RoBANS): Development and validation of a new instrument. In: Abstracts of the 19th Cochrane Colloquium; 2011 19-22 Oct; Madrid, Spain. John Wiley \& Sons; 2011.

Contributors: SC and NKA conceptualised the research. SC and NKA conducted the systematic review with inputs from SP. SC wrote the first draft and NKA and SP revised the manuscript.

Funding: The authors did not receive any funding for this study from any funding agency in the public, commercial, or not-for-profit sectors. 
medRxiv preprint doi: https://doi.org/10.1101/2021.03.21.21254068; this version posted March 23, 2021. The copyright holder for this preprint (which was not certified by peer review) is the author/funder, who has granted medRxiv a license to display the preprint in perpetuity. It is made available under a CC-BY-NC-ND 4.0 International license.

727 Competing interest: Authors declare no competing interest.

728 Patient and public involvement: No direct involvement of patients or the public.

729 Patient consent for publication: Not required.

730 Data availability statement: All relevant data are either included in this article or added to

731 the supplementary information. 
medRxiv preprint doi: https://doi.org/10.1101/2021.03.21.21254068; this version posted March 23, 2021. The copyright holder for this preprint (which was not certified by peer review) is the author/funder, who has granted medRxiv a license to display the preprint in perpetuity.

It is made available under a CC-BY-NC-ND 4.0 International license .

764

765

766

767 